\title{
Capital Structures: Vectorizing the Harrod-Domar Model in Macro-Economics
}

\author{
Frederick Betz \\ Disequilibrium Economics Inc., Seattle, WA, USA \\ Email: fbetz@venture2reality.com
}

How to cite this paper: Betz, F. (2018) Capital Structures: Vectorizing the Harrod-Domar Model in Macro-Economics. Theoretical Economics Letters, 8, 2682-2706. https://doi.org/10.4236/tel.2018.812170

Received: May 28, 2018

Accepted: September 14, 2018

Published: September 17, 2018

Copyright $\odot 2018$ by author and Scientific Research Publishing Inc. This work is licensed under the Creative Commons Attribution International License (CC BY 4.0).

http://creativecommons.org/licenses/by/4.0/

\begin{abstract}
The epistemological status of economic theory is either as an idealistic prescription or a depiction of a factual reality in context. We examine the reality of the macro-economic model of Harrod-Domar in the context of the Japanese, Korean and American economic history. Empirically, one sees that the model remained ideal but incomplete in fact. The capital structures in an economy determined whether capital flowed ideally or otherwise. This is a cross-disciplinary research approach combining the economic perspective with the management perspective in the disciplines of the social sciences.
\end{abstract}

\section{Keywords}

Macro-Economics, Institutional Economics, Capital Flows, Financial Systems, Theory of the Firm

\section{Introduction}

Macro-economics is the part of economic theory which deals with the relation of capital to productivity in an economy. Historically, the formulation of economic growth models took a major change when John Maynard Keynes reformulated traditional economic models. Hendrik Van den Berg wrote: "When Keynes published his General Theory in 1936, the neoclassical paradigm was well-established in the economics profession. Even though the Great Depression weighed heavily on economists' minds, economists were somewhat hesitant to jump to a new paradigm that seemed to contradict conventional mainstream economic thought. Most mainstream economists were more accepting of Hicks' interpretation of Keynes' General Theory, which omitted Keynes' more complex and radical ideas... (and afterwards) the growth models were derived from Keynesian macroeconomic foundations by Roy Harrod and Ev- 
sey Domar.” [1].

It is useful to treat the Harrod and Domar models as basically similar. Hendrik Van den Berg wrote: "Harrod and Domar independently developed what turned out to be identical growth models, which we now refer to as the Harrod-Domar model. That two economists would independently produce the identical model was not surprising; their models were logical extensions of the same Keynesian macroeconomic model. In analyzing how macroeconomic policy could restore full employment, Keynes had focused on aggregate demand, especially the potentially volatile component called investment. Harrod and Domar pointed out that investment changed the economy's supply side as well as the demand side, and full employment could be maintained only if investment and the other sources of aggregate demand grew just fast enough to exactly absorb the increased output that the new investment made possible." [1].

The Harrod-Domar model consisted of two parts, a supply-side model of production and a demand-side model of demand. For the supply-side, the Harrod-Domar model posited two equations:

1) A constant marginal product of capital means the economy exhibits a constant capital-output ratio $K / Y_{S}=\gamma$, so that the supply of output $Y_{S}$ is proportional to the stock of capital $K: Y_{S}=1 / \gamma K$.

In a steady state of production, the quantity of production $Y_{S}$ is proportional to the capital $K$ invested in production capacity by the factor of $(1 / \gamma)$.

2) An increase in capital $\Delta K$ creates a proportional increase in production $\Delta Y_{S}$

$$
\Delta K=\sigma \Delta Y_{s}
$$

Increase of Production $\Delta Y_{s}$ occurred proportionate to an increase in Capital $\Delta K$.

The hypothesis of the Harrod-Domar model is that all savings $S$ goes into productive investment $I_{S}$ and all productive investment goes into capital $K: S=I_{S}$ $=K$. Thus the key assumption is that Savings (S) in an economy needs to be invested into Production (P). This is an ideal function of savings in an economy, as productive investment. Figure 1 summarizes the algebraic equations of Harrod-Domar and translates these into a systems graphic representation [2].

One can note that in systems graphic depiction, flows are depicted by "arrows" in the direction of the flow; sources-of-a-flow are depicted by a "cloud" symbol; stocks by a "rectangle" symbol; and control-of-a-flow by the triangle-over-an-oval' symbol. The Harrod-Domar algebraic model is represented by capital flow from savings $S$ to investment $I_{S}$ to capital $K$ into production $Y_{\mathcal{S}}$ with flows controlled by the proportionate factors.

One advantage of systems notation is that one can improve upon the algebraic form by introducing controls in the flows from savings $S$ to investment $I$ to capital $K$. Savings and investment and capital may not all be in equal ratio, and one can add more proportional factors to relate variable levels of transformation of savings to investment to productive capital: $\tau$ is the ratio of savings $S$ 


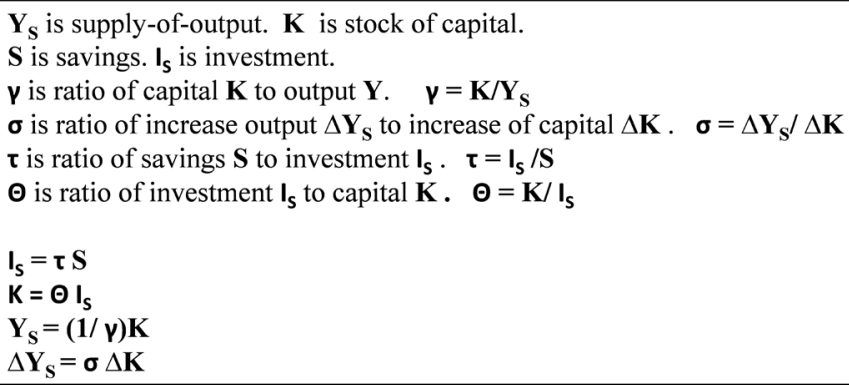

Figure 1. Harrod-Domar macro-economic model of savings \& production, graphic systems dynamics representation of the supply-side of the harrod-domar model.

to investment $I_{S}: \tau=I_{S} S S . \Theta$ is the ratio of productive capital $\Delta K$ to investment $I_{S} \Theta=\Delta K / I_{S}$

In this kind of macro-economic model, a key assumption is that the capital structure of the activity of Savings $S$ is not important. This is to say, that the institutional organization of how Savings $S$ is formed and how it is invested $I_{s}$ into Production is neither economically important nor relevant. But what if this is not empirically true? What if how the Savings is invested into Production in a national economy is relevant to economic growth? We investigate this proposition by analyzing different capital structures in different national economies, using technique of strategic business models.

\section{Capital Structures}

Explanations in the economic discipline have been not only in macro theory (such as the Harrod-Domar model) but also in historic studies (such as economic histories of events) and also in institutional descriptions. What we wish to do is to connect macro-theory explanation with institutional explanation. In this research, we integrate these three kinds of explanation: models, cases, and institutions. We do this through analyzing the institutional control of capital flow in an economy, which we call a "capital structure". A "capital structure" the organization of institutions in an economy controlling the flow of investments into financial use.

Then the institutional concept of a "capital structure" can then be compared to a Harrod-Domar model (connecting the flow of Savings to Production). We compare three historic cases of capital structures: the Japanese industrialization period (1860s-1960s), the South Korean industrialization period (1950-2000), and the American Wall Street investment bank history (1952-2008).

A capital structure can be described as how investment banks institutionally 
move savings $S$ into investment $I$. The institutional movement of capital has in economic theory been partly discussed in what has been called the "theory of the firm"-tracing back to Berle and Means' study of control in publicly held corporations [3]. Even later theory looked at firms as transformational activities producing products [4]. To model a capital structure, we use Porter's modeling approach as to how firms use capital, called a "strategic business model".

We begin by reviewing the Porter approach. As shown in Figure 2, an enterprise system is an open-system (transforming inputs of resources to outputs of product sales); and this is also shown is Michael Porter's goal-directed-transformation, depicted as kind of "arrow".

For a production enterprise, the system consists of the coordinated set of productive activities (purchasing, production, inventory) which adds value to resources purchased from the market environment and then sold back into the market as products. Porter's model adds overhead functions to the direct production (transformation) center of the open system model.

In this 2-factor model, Resources and Sales provide two basic factors for the direct production transformations of a business operation. But there are also two other basic factors, Profits and Capital, that are necessary to an enterprise system. These indicate the factors needed for adding monetary-value in business operations. Profit is a measure of business efficiency (the difference between prices and costs of sold products/services). Capital is a measure of the asset value of the business, equity as the stock value.

Using these, a more general form of business models was constructed as a 2-input and 2-output four-factor model of: Resources, Sales, Profits, Capital [5]. How many types of "business models" can be constructed? Logically, one can list all possible $2 \times 2$ types of enterprise-open-systems by taking all combinations of the four categories (resources, sales, profits, capital) two-at-a-time as inputs and as outputs. Ignoring the order of factors in a combination, one can construct six different models to describe a business, as shown in Figure 3.

The upper box lists the four strategic factors which can be used to construct a strategic business model. The lower box takes them two at a time, as either inputs or outputs, and lists their six logical combinations (ignoring the order of the factors in a combination). The oval depicts the environment for a strategic business model with two inputs and two outputs. Figure 4 sketches the six different forms of strategic business factors.

The type 1 model corresponds to Porter's value-added transformation model, with the addition of invested capital as a second input and profits as a second output. A business model depicts the operations of a current business in its present competitive situation; and a strategic business model depicts the future operations of the business to face an anticipated future competitive situation. Manufacturing firms, retail firms, financial firms, and even a holding company can be described by these forms. A holding company controls the capital of the portfolio businesses; and a holding company is dominant form of large global 


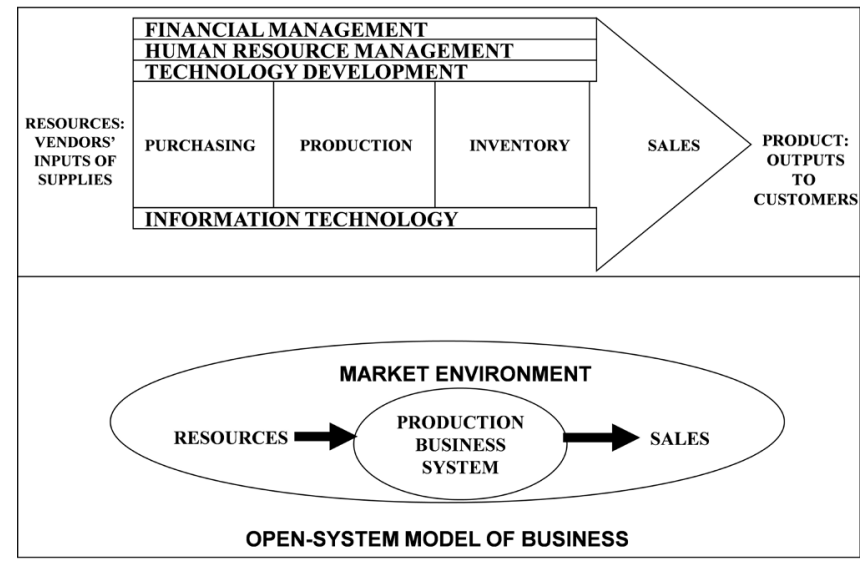

Figure 2. Firm as an enterprise system and porter's value-added open-system model, michael porter's value-added (open-system) model of a business enterprise.

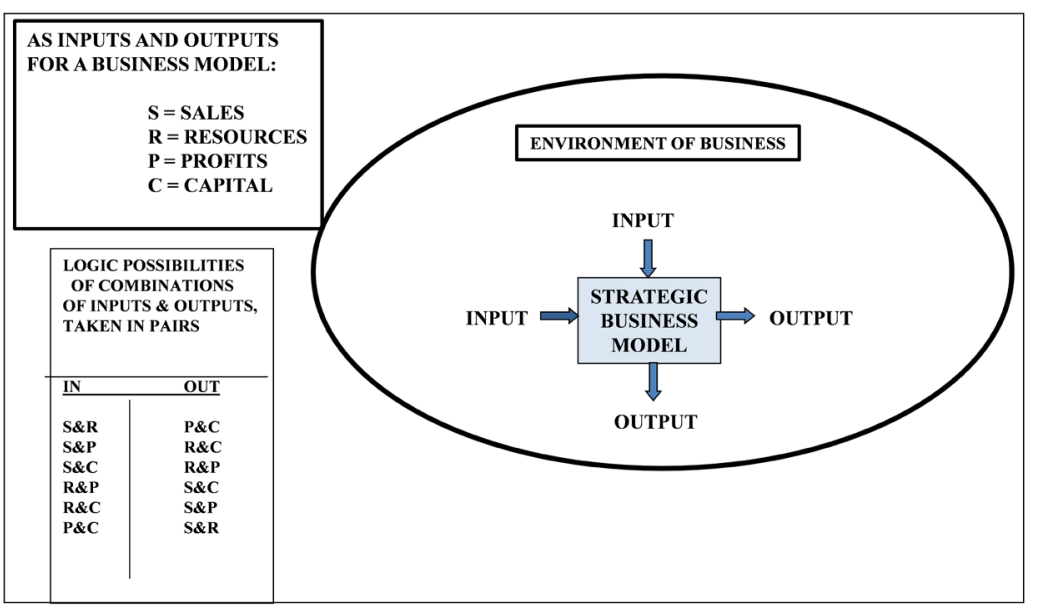

Figure 3. Two-inputs and two outputs strategic business models, two-inputs and two-outputs value-added business models of an enterprise system.

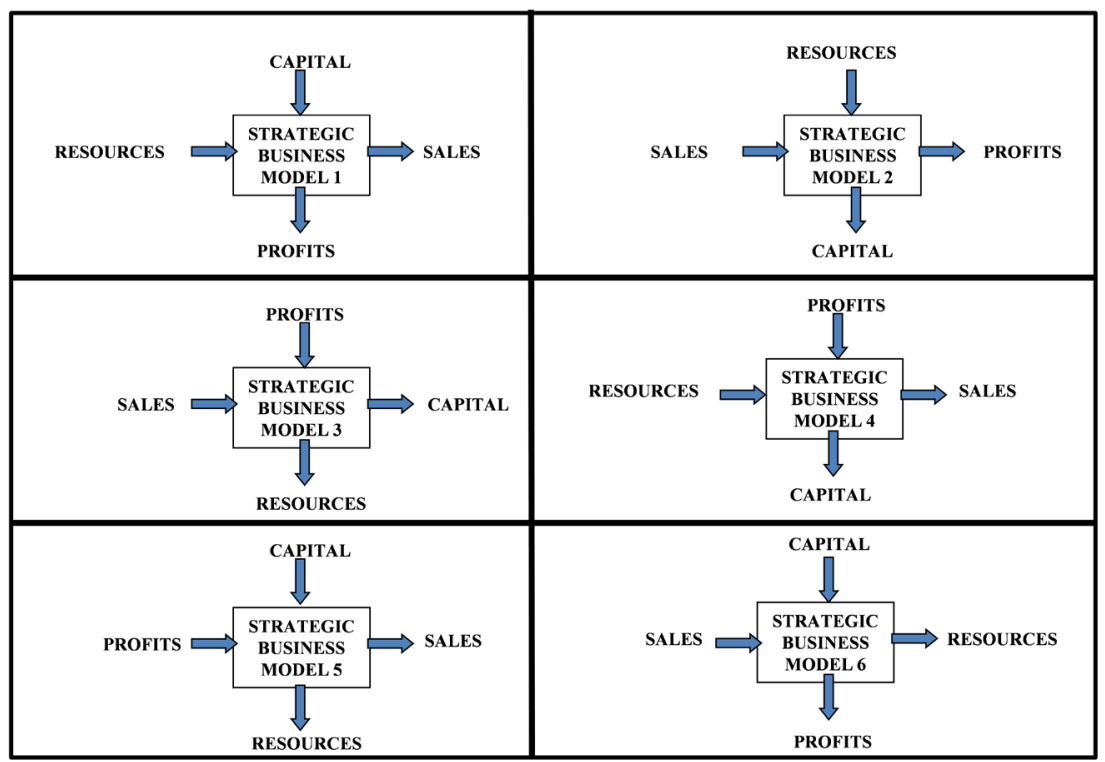

Figure 4. Six-types of strategic business models, six types of strategic business models. 
companies. In particular, the holding company provides a strategic way to control businesses-a strategic control which structures the capital expenditures in an economy. In Figure 5, we depict a strategic business model for a holding company, containing portfolio-owned businesses.

For a holding-company, the financial market is principle strategic focus, valuing the equity capital of the firm. In contrast, the businesses a holding company owns (portfolio businesses) attend to their customer markets, in which they sell their products. The sales and profits of the portfolio businesses are reported as inputs (revenue and sales) to the holding company.

The form of a holding-company is important to economic theory because this form (in the theory of the firm) directly controls the flow of capital as its strategic output. Moreover, all global corporations are now in the form of a holding-company, so that this form structures the capital flows in most national economics (capital structure). Figure 6 shows how a capital structure (of holding-companies) can show the impact of strategic control of a holding company on the flow of capital in an economy.

By vectorizing the Harrod-Domar equation, one can distinguish between different kinds of investment capital structures $I_{J}$ and the different kinds of uses of capital $Y_{J}$. These different capital structures $I_{J}$ can be depicted by the kind of holding-company in the structure, controlling the flow of capital into investment.

In this model of capital structure, holding companies direct capital toward different economic goals, such as maintaining Production $\mathbf{Y}_{\mathrm{S}}$, increasing Production $\Delta \mathrm{Y}_{\mathrm{S}}$, decreasing Production $-\Delta \mathrm{Y}_{\mathrm{S}}$, or stock market $\mathrm{M}$. This idea of strategic control comes from the domain of management theory in business schools; and the idea of capital flow is from economic theory.

This addition of a capital structure into the Harrod-Domar model in graphic form occurs by expanding the variable of investment $I_{S}$ into an institutional explanation and allows the explanation of where capital flows, sometimes not into Production but into a Stock Market. This improves the modeling of the empirical reality of business in an economic system of a nation. We next examine the control strategies of Bershire Hathaway in the U.S. and of the Keirutsu and Chaebols in Japan and South Korea. Different forms of a holding-company in different nations have structured their national economies in different ways.

\section{Case: Berkshire Hathaway as a Holding-Company Form of a Capital Structure}

In order to illustrate the use of a vectorized model, we briefly review the case of a US Berkshire Hathaway. In 2015, Berkshire Hathaway Inc was a holding company which had a business portfolio of wholly owned businesses, which included GEICO, BNSF Railway, Lubrizol, Fruit of the Loom, Helzberg Diamonds, Flight Safety International, Pampered Chef, and NetJets. In addition, Berkshire owned shares in many companies including: $26.7 \%$ of the Kraft Heinz Company, 


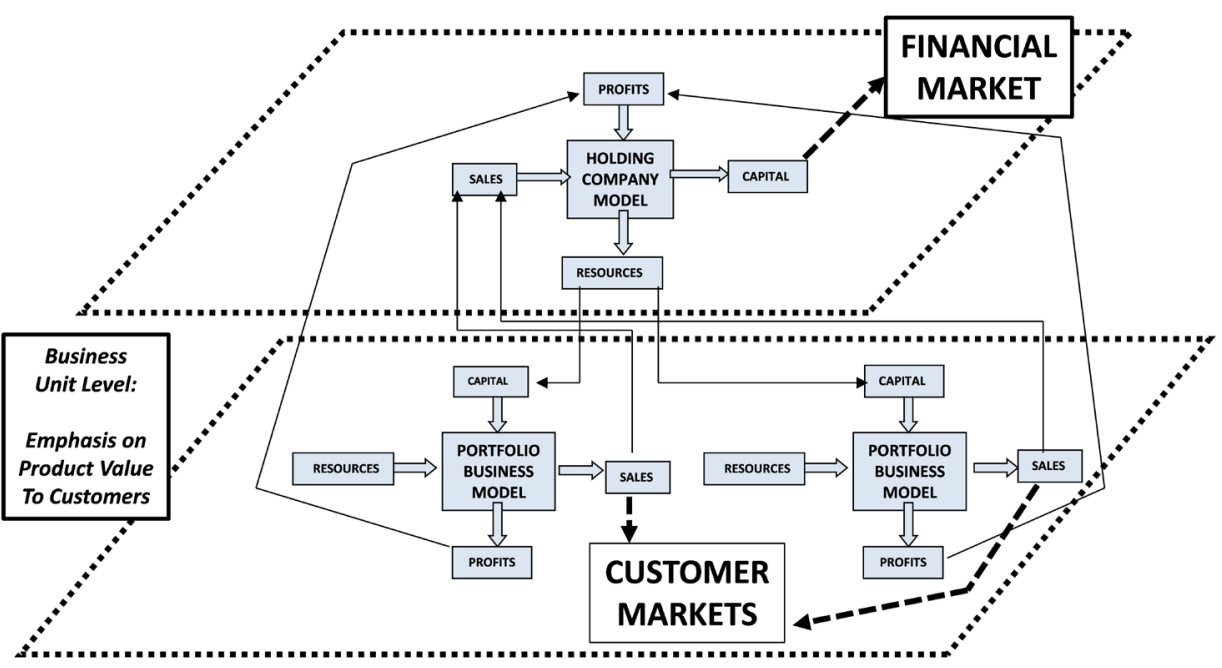

Figure 5. Strategic business model of a holding-company, strategic business models of a holding company.

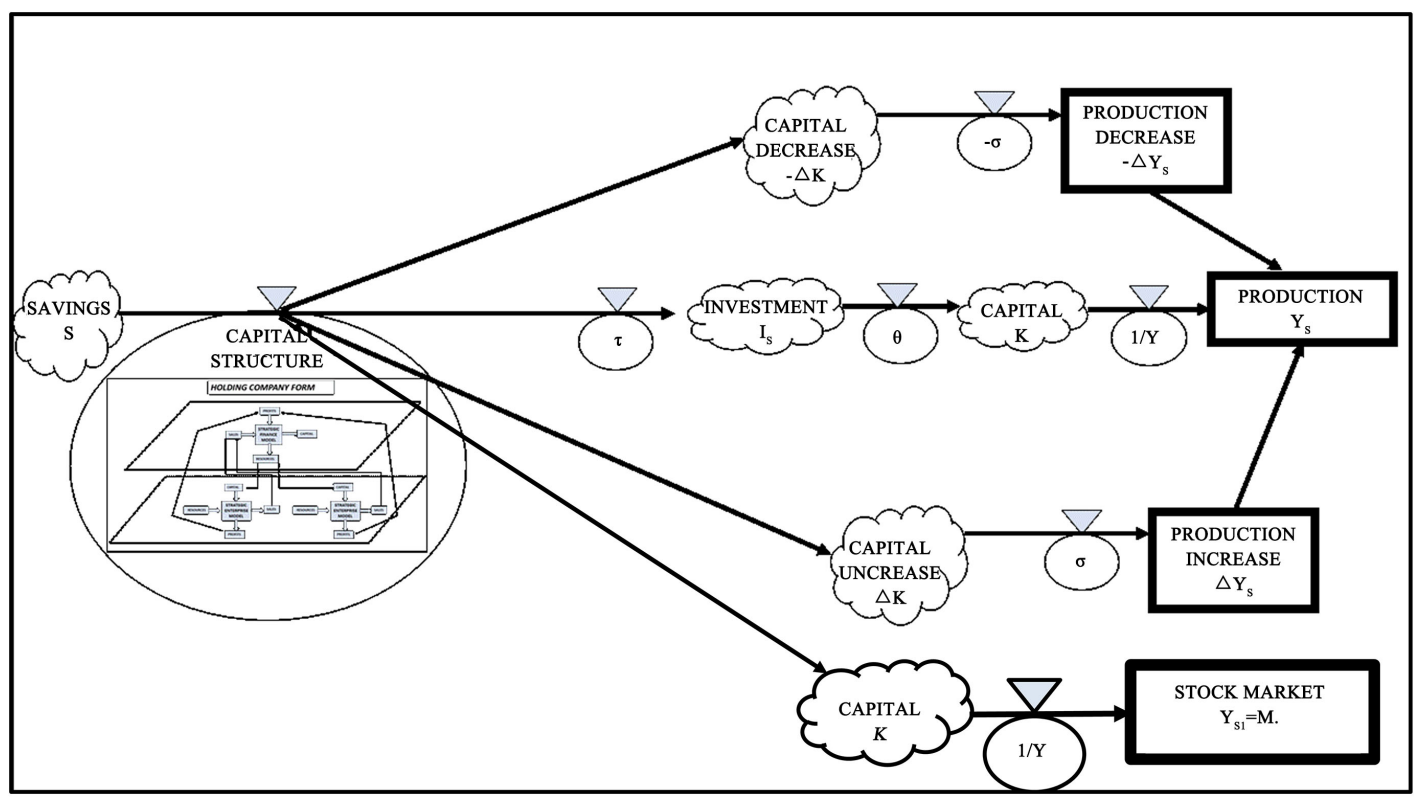

Figure 6. Holding companies of a capital structure directing flow of capital in $\mathrm{n}$ economy, holding companies in a capital structure directing flow of capital in an economy.

17\% of American Express, 9.4\% of Coca-Cola Company, 9.9\% of Wells Fargo. $6.9 \%$ of IBM, and $2.5 \%$ of Apple. Berkshire also has significant holdings in United Airlines, Delta Airlines, Southwest Airlines, and American Airlines [6].

Warren Edward Buffett was born in 1930. His interest in the stock market and investing followed from his father's occupation. His father, Howard Buffet, was in the stock-investment business and, in 1942, was elected as a Republican representative from the Omaha district to the U.S. House of Representatives. He served three terms in the house. He was defeated in 1948 for a consecutive fourth term but returned in 1950 to win another term. Then he decided to return to his investment business in Omaha. 
In high school, Buffett began investing in stock. He attended the University of Pennsylvania for two years and then transferred to the University of $\mathrm{Ne}$ braska in Lincoln, graduating with a Bachelor of Science degree in business. He next entered the Business School of Columbia University. In 1951, he graduated with a Masters degree in Economics in 1951. He returned to Omaha and worked at his father's firm, Buffett-Falk \& Co. as an investment salesman until 1954.

While at Columbia, Buffet attended lectures by Benjamin Graham, about "value investing". In 1954, Buffett worked at a security analyst in Benjamin Graham's partnership. In 1956 Benjamin Graham retired, and Buffet started his own investment partnership, Buffett Partnership Ltd. By 1960, Buffett was running seven limited partnerships investing in stock. In 1962, the partnerships were worth $\$ 7$ million, of which Buffett's share was $\$ 1$ million. He began buying shares in Berkshire Hathaway, a textile manufacturing firm, finally selling off the textile mills in 1985, but retaining the name of the firm.

Buffet then bought into the insurance business. In 1996, Berkshire Hathaway bought the Government Employees Insurance Company (GEICO), offering automobile insurance. In 1967, his firm, Berkshire, bought National Indemnity Company. In 1998, Berkshire acquired General Re, operating in the reinsurance business. In 2007, Berkshire bought Nederlandse Reassurantie Groep (NRG), a Dutch life reinsurance company. Berkshire also started Berkshire Hathaway Assurance to provide insurance to U.S. municipal and state bonds.

One can strategically model Berkshire Hathaway as a holding company but with three kinds of business models, one for the holding company, another for the insurance business, and a third for the production businesses. This is shown in Figure 7.

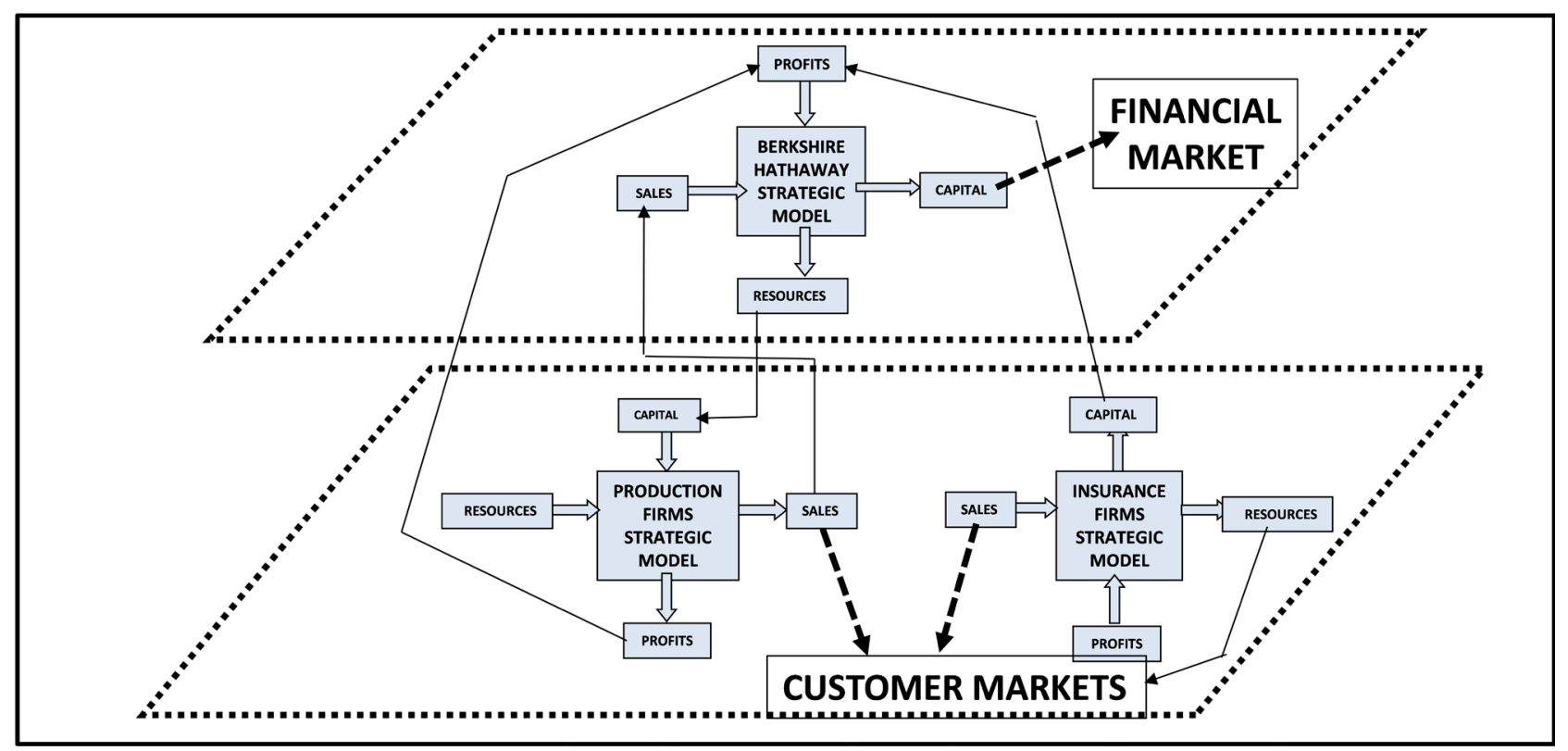

Figure 7. Berkshire Hathaway strategic business model, strategic business models in the holding company of Birkshire Hathaway. 
At the holding-company level, a strategic model shows the emphasis on Capital as an output, particularly the stock-market value of the firm. In contrast, the strategic models for each of its businesses show emphasis on sales to customers. A holding-firm can use profits from portfolio business sales and profits to increase its capital. The diversified firm has responsibility for seeing that its businesses are well managed, for profits from their businesses need to continue to provide corporate prosperity.

The insurance group in Berkshire Hathaway enabled Buffet to buy operating companies which had steady profits. The Capital from insurance premium of the insurance businesses is their Outputs which are fed into the Profit Input of Berkshire Hathaway. This Capital Input enables Berkshire Hathaway to buy more production businesses. The Profits as Outputs from the production businesses also provide Profit Inputs to Berkshire Hathaway. The conglomerate used insurance businesses to generate the capital needed to buy production businesses to send their Profit Outputs to Berkshire Hathaway. It is the insurance businesses of the Buffet's conglomerate that provide the capital to continually to buy new and profitable production businesses-continuously growing the conglomerate.

Buffet also had not split Berkshire Hathaway shares, so that a single share has over the last two decades has ranged from $\$ 100,000$ per share to over $\$ 200,000$ per share. At that price, it is difficult for a hedge fund to purchase enough shares to take control away from Buffet.

Peter Eavis and Stephen Grocer wrote: "Berkshire recorded a hefty windfall from the tax bill that Congress passed at the end of last year (2017). The annual report said the tax overhaul produced a $\$ 29.6$ billion gain that was offset slightly by $\$ 1.4$ billion of tax payments on repatriated foreign earnings. The tax gain contributed nearly two-thirds of Berkshire's $\$ 44.9$ billion in net earnings for 2017. Each year, Mr. Buffett highlights the change in Berkshire's book value, a measure of the company's net worth. In one year, the company's book value rose by $\$ 65.3$ billion to $\$ 348$ billion in 2017, a 23 percent gain from $\$ 282$ billion at the end of 2016. The tax benefit made up a hefty 45 percent of the book value increase. In commenting on the contribution from lower taxes, Mr. Buffett said: "The $\$ 65$ billion gain is nonetheless real-rest assured of that." ...One of main ways that Berkshire has grown over the years is by spending large sums to acquire other companies." [7].

It is important to note two features in this model of Bershire Hathaway's strategy as a holding company: the portfolio businesses attend to their customer markets, while the holding company attends to its financial market. This is why a "holding-company" model of business activity is central to understand capital flow in an economy. The holding-company directly focuses business on the capital market of its environment-the capital structure.

\section{Berkshire Hathaway as an Institutional Form of a Capital Structure}

With this holding-company model of Berkshire-Hathaway' control of capital, we 
can now insert this institutional model into a Harrod-Domar model, as a capital-structure on the investment source $I_{S}$. To do this, we generalize the algebraic expression of the Harrod-Domar model into a vector equation. (A vector equation differs from an algebraic equation by "indexing" the variables of the algebraic equation.) We generalize the Harrod-Domar model into vector equations:

$1 / \gamma K_{J}=Y_{S J}$ where $K_{J}$ is the J-th kind of capital flow to economic use $Y_{S J}$ $\Delta K_{J}=\sigma \Delta Y s_{J}$ where $\Delta K_{J}$ is the $J$-th kind of increase in capital flow to increase economic use $\Delta Y_{S J}$

\section{$\tau S_{\mathrm{J}}=I_{S J}$ where $S_{J}$ is the savings into the J-th investment kind $I_{S J}$}

By introducing vectorized variables (indexed by the J-th subscript), we can distinguish the types of capital focused upon by a holding company. Now we index $\mathrm{J}=1$ to indicate a Berkshire-Hathaway type holding company. The Harrod-Domar vector graphics shown in Figure 8.

Berkshire Hathaway acquires portfolio businesses and buys into the stock of businesses to increase the value of its shares in the stock market-to increase wealth. Thus for Berkshire Hathaway (index $\mathrm{J}=1$ ) the capital $K_{l}$ goes not into production $\mathrm{Y}_{\mathrm{S}}$ nor to increase production but into the stock market $Y_{S 1}=M$. The holding company of Berkshire Hathaway does not increase production in the U.S. economy but, instead, redistributes wealth in the stock market $M$. This is a realistic depiction of the contribution to the capital structure of the U.S by Berkshire Hathaway-which is not economically ideal (to increase production) but economically real (to increase wealth). A vectorized Harrod-Domar model allows the depiction not only idealism in macro-economics but also empirical realism.

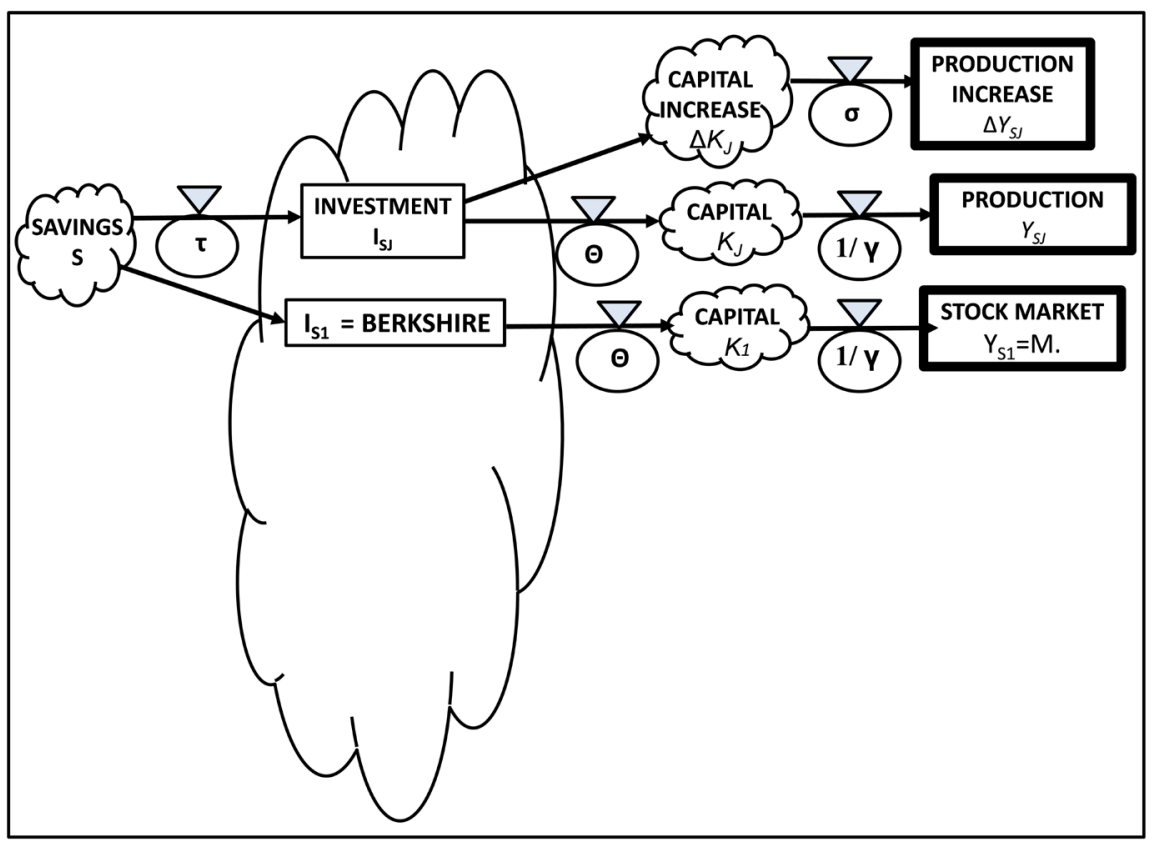

Figure 8. Berkshire Hathaway investment $I_{S 1}$ into the stock market $Y_{S 1}$, Berkshire Hathaway investment in stock market. 


\section{Zaibatsu/Keiretsu in Japan}

Buffett's form of U.S. business conglomeration (with a financial business, insurance, providing capital for the purchase of production businesses) has an interesting historical precedent. In the industrialization of Japan in the twentieth century, such a form was called a "zaibatsu" and provided the means of economic growth in the new Japanese economy, of the Meiji Restoration. With a bank at the center of a group of businesses, the Japanese zaibatsu organized the Japanese economy up to and through the Second World War.

From the 1850s to the 1915, Japan transformed itself from a feudal society into an industrial society. This occurred after U.S. warships arrived in Edo harbor, convincing the samurai that they were behind the world in military power. Two samurai clans then overthrew the Tokogawa shogun government and established a modern government, with a modern military and economy.

Some merchants formed modern banks and built industrial groups around each bank, called a zaibatzu. Hidemasa Morikawa wrote: “The Meiji Restoration of 1868 led to the establishment of a modern economic and political infrastructure, which laid the basis of Japan's industrialization. These years encompassed the introduction of the joint-stock company, formation of a modern banking system, development of railway and steamship line, modernization of cotton spinning through the importation of machinery and factor system, and application of steam power to mining... During this phase the founders of the zaibatsu accumulated their wealth." [8].

In the Meiji restoration, the new government dissolved the warrior ruling class, the samurai. Former samurai had to become merchants or government officials or military officers. The enterprising samurai, involved in money-changing, established the first banks and funded commercial businesses in production and trading.

Albert J. Alletzhauser wrote: "Zaibatsu", meaning financial clique or "estate wealth", is a modest phrase for the family-run industrial empires, which rose to prominence during the Taisho (1912-25) and Showa (1926-88) eras... Every zaibatsu house was dominated by a family patriarch, usually a man of samurai descent. It was the samurai who, at the beginning of the Meiji period in 1868, had used their government contacts to win concessions and licenses. At the core of each zaibatsu lay the family bank, which funded the dozens of other family endeavors." [9].

In the early twentieth century, there were four major zaibatsu which dominated Japan's newly developed industry: Mitsui, Mitsubishi, Sumitomo, Yasuda Alletzhauzer wrote: "Central to each house was also the family trading firm, with outposts worldwide, used not only to buy and sell goods... Funded by the bank, raw materials were brought by the trading companies and merchandise produced by the manufacturing arm and sold back out through the trading company. They were everywhere: from steel to railways, textiles to chemical, banking to mining, shipbuilding to trading... four zaibatsu towered over the entire Japanese 
economy." [9].

Hidemasa Morikawa wrote: "The political merchants (from feudal Japan) that developed into major zaibatsu can be divided into three groups according to the kinds of services they provided the Meiji government: first, Mitsui and Yasuda, financiers licensed to handle national tax revenues; second, Okura and Fujita, merchant enterprises that supplied goods and services required by the regime; and third Mitsubishi, which received special subsidies from the government for shipping operations." [8].

The history of the Mitsui Group traced back to 1616, when a former samurai gave up his status to marry a merchant's daughter. He began a small brewery to make sake and soy sauce. Then his wife and children added a small drapers shop and money exchange. Sometimes, customers spent more than they had cash, and Shuho would loan money, accepting some valuable as a security. In this way, Shuho began the first expansion of the family business, from sake and soy sauce to pawn brokering, with interest on the loans soon becoming more profitable than brewing. Sokubein died in 1633, and Shuho continued to run the family business. She sent her eldest son to Edo in 1673 with capital to open a draper's shop, called Echigoya, which prospered. Later in 1866, the Mitsui family had a talented servant, Minokawa Rihachi, who transitioned the Mitsui family business into a zaibatzu. When the Tokogawa Shogunate was overthrown Mitsui was selected by the new Meiji government to provide financial services and handle the creation of a new currency. Mitsui was also instructed to begin preparation for the creation of a central bank for Japan. In 1876 Mitsui formed the Mitsui Bank, a major financial institution in Japan in the years ahead.

The Yasuda zaibatsu was established by Yasuda Zenjiro to provide financial services to the government, at the end of the Tokogawa Shogunate, Yasuda founded the Third National Bank of Japan in 1876.

The Mitsubishi (Three Diamonds) zaibatsu was founded by a samurai, Iwasaki Yataro. Iwasaki served the government by raising taxes and purchased weapons from foreign merchants. When the Meiji government occurred, Iwasaki provided shipping for the new government, establishing the Mitsubishi Mail Steamship Company. Mitsubishi provided military transport.

In contrast, the Okura zaibatsu was founded by a peasant, instead of a samurai. Okura Kihachiro began selling grocery and then guns in 1857. Okura traveled to Europe in 1872 with other young samurai. On returning to Japan, he obtained government contracts from acquaintances he made with government people who also visited Europe. The company provided military supplies to the government.

Also, the Sumitomo zaibatsu came from a merchant family back in 1590, when Soga Riemon began a copper refinery in Kyoto. His eldest son married a daughter of Sumitomo Masatomo, a wealthy merchant in 1590 and adopted the Sumitomo surname. When the Shogunate was overthrown in 1868, Sumitomo continued in mining and became a modern zaibatsu. 
Figure 9 depicts the Japanese $s \backslash$ zaibatsu as a holding company.

In a family-owned zaibatsu, a group bank funded the group's business empire of production and trading firms. The Capital of the zaibatsu bank, as an Output, provided investment Capital to begin and grow the production and trading firms of the group-as Capital Input into the portfolio businesses. The Profits as Outputs of the zaibatsu portfolio-companies provide Profit Input to the zaibatsu bank. Savings deposits into zaibatsu bank (as Sales input) also provide a source of Capital for the bank. (And we note that zaibatsu banks were not traditional forms of banks, because they did not provide loans as sales to outside customers; instead a zaibatsu bank provided loans only to its zaibatsu companies.)

The zaibatsu organized industrial efforts and were close to governmental parties and military. For example, RikkenSeiyūkai political party was funded by the Mitsui group and had connections to the officers in the Imperial Japanese Army. The RikkenMinseitō party was funded by the Mitsubishi group and had connections to officers in the Imperial Japanese Navy. When the Second World War began, the four largest zaibatsu (Mitsui, Mitsubishi, Yasuda, and Sumitomo) controlled $30 \%$ of Japan's industries in mining, chemicals, and metals. They controlled $50 \%$ control of the machinery industry and $70 \%$ of stock exchange activity.

After Japan's defeat in World War II, the U.S. occupation ordered the zaibatsu to break up but rescinded the order when the Korean War began, as the U.S. needed supplies and stationing for the war. The zaibatsu morphed into Keiretsu, still a group of companies centered around a bank (but no longer necessarily a family-owned bank). Figure 10 lists some of the keiretsu in modern Japan.

We see that the Mitsui group (keiretsu) has the Sakura Bank as its core, along with the Mitsui Trust and Banking. The Mitsubishi keiretsu has the Bank of Tokyo, Mitsubishi Bank and Mitsubishi Trust \& Banking as the core financial institutions of the Mitsubishi Group. And so on.

\section{Korean Chaebols}

South Korean holding companies, chaebols, originated in the industrialization of South Korea after Korea's liberation from Japanese occupation in 1945. The chaebols are Korean family-controlled groups of businesses, which became the capital entrepreneurs for the Republic of Korea's government under Park Chung Hee, to build the modern, industrialized South Korea. Some Korean chaebol began as family enterprises during the 1930s under the Japanese occupation. Others after the liberation of Korea in 1945. Of the fourteen largest chaebols in 1960, six had begun under the occupation and eight under Rhee's government.

Korean enterprises surviving under Japanese occupation had not been not easy. Some form of cooperation with Japanese officials and enterprises was necessary for Korean businesses to survive during the occupation. Myung Hun Kang wrote: "A distinctive pattern of investment portfolios and election to corporation boards was apparent by the last decade of the colonial period. The pattern 


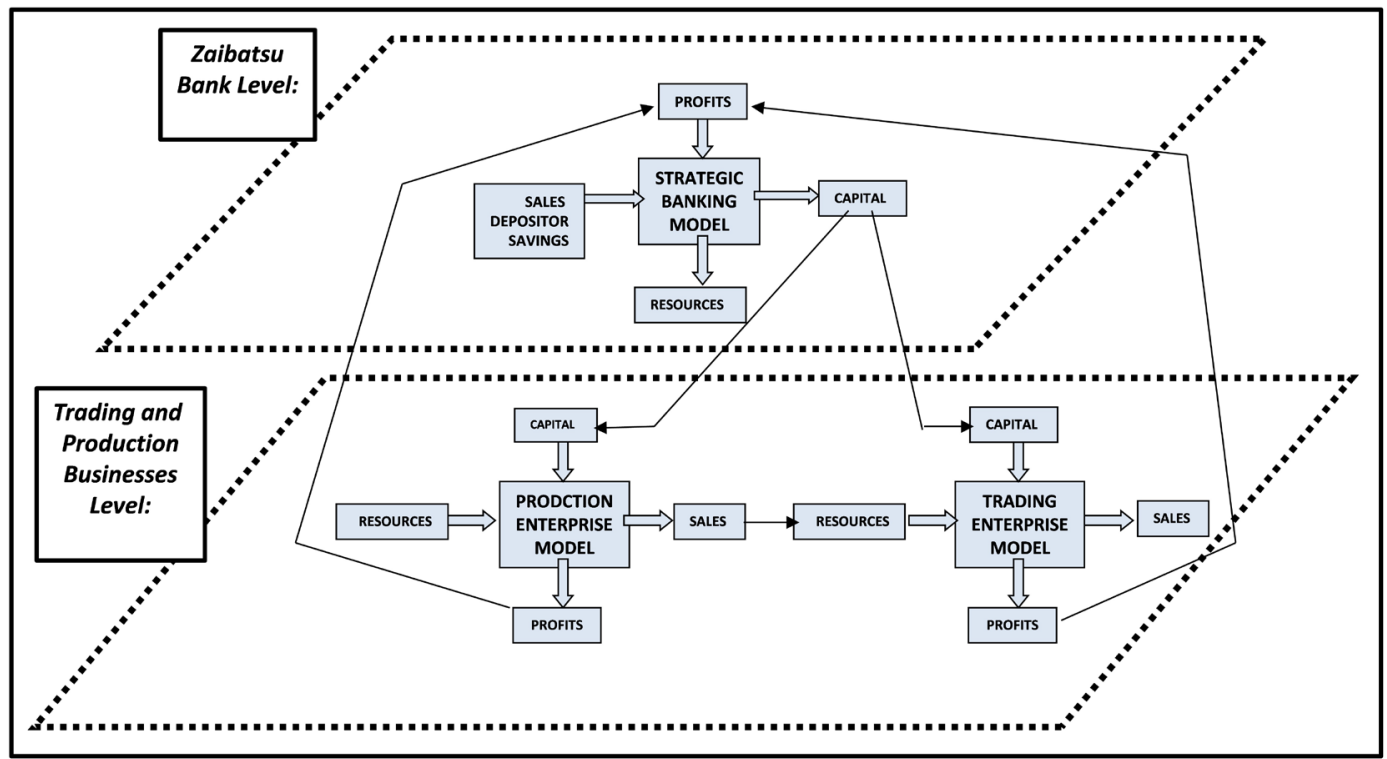

Figure 9. Strategic business model of Japanese zaibatsu, strategic business model of a Japanese zaibatsul keiretsu.

\begin{tabular}{|l|l|l|l|l|l|l|}
\hline Industry & Mitsui & Mitsubishi & Sumitomo & Fuyo & Sanwa & DKB \\
\hline Banking & Sakura Bank & $\begin{array}{l}\text { Bank of } \\
\text { Tokyo- } \\
\text { Mitsubishi } \\
\text { Bank }\end{array}$ & $\begin{array}{l}\text { Sumitomo } \\
\text { Bank }\end{array}$ & Fuji Bank & Sanwa Bank & $\begin{array}{l}\text { Dai-lchi } \\
\text { Kangyo Bank }\end{array}$ \\
\hline Trust Banking & $\begin{array}{l}\text { Mitsui Trust \& } \\
\text { Banking }\end{array}$ & $\begin{array}{l}\text { Mitsubishi } \\
\text { Trust \& } \\
\text { Banking }\end{array}$ & $\begin{array}{l}\text { Sumitomo } \\
\text { Trust \& } \\
\text { Banking }\end{array}$ & $\begin{array}{l}\text { Yasuda Trust } \\
\text { \& Banking }\end{array}$ & $\begin{array}{l}\text { Toyo Trust \& } \\
\text { Banking }\end{array}$ & \\
\hline
\end{tabular}

Figure 10. Keiretsu in modern Japan, industrial group of keiretsu.

included four concentric levels of business activity. First an inner core of family-owned companies, usually in agriculture and real estate... The second level of investments included major investments with administrative responsibility in complex joint-stock enterprises... A third level included smaller investments in medium-sized ventures, without major administrative responsibilities... a team of major Korean entrepreneurs and a few Japanese government officials. A fourth level... was minor participation of Korean capital in... large Japanese investments in the peninsula." [10].

After the war, Korean families built the industry of South Korea were holding companies controlled by the founding family. The government encouraged the growth of the chaebols as a way to develop South Korea and assisted with encouraging Korean banks to loan money to the chaebols.

\section{Zaibatsu/Keiretsu and Chaebol Institutional Forms of a Capital Structure}

We can now depict how the holding companies as zaibatsu/keiretsu in Japan and as chaebols in South Korea provided capital structures for their respective nations' economic development in the vectorized Harrod-Domar model, Figure 
11. The J-th index is set at 2 for either a zaibatsu/keiretsu or a chaebol.

We see that the capital $K_{2}$ was used by the holding-companies, as bank-centered or family-centered, to fund new productive enterprises and grow the economy $\mathrm{Y}_{\mathrm{S} 2}$ in their society. This use of capital for production was both ideal and real economically.

\section{Venture Capital Funds}

Traditionally in the first half of the twentieth century in the United States, investment banks helped in funding the start-up of companies. They put together investments from wealthy individuals for entrepreneurs desiring to start new companies. In the second half of the twentieth century in the United States, venture investment funds took over the task of funding new ventures.

For example, after the invention of recombinant DNA in biotechnology, many new biotech firms were started funded and by venture funds. This continued with the progress in biotechnology. In 2018 one of the new technologies was to precisely cut DNA and was called Crispar. Clive Cookson wrote: "A US start-up has joined the race to commercialize Crispar, the gene editing tool that is transforming biotechnology. Pioneers of the field at Harvard University and Massachusetts Institute of Technology have launched Beam Therapeutics with $\$ 87 \mathrm{~m}$ initial venture capital funding. Beam is the first business to use 'base editing', a technique developed by the company's co-founders, David Liu an Feng Zang, to treat disease. The financing is led by F-Prime Capital Partners and Arch Venture Partners... The founders of Beam... recently set up yet another gene editing company, Pairwise Plants, which announced funding in March. It will apply Crispr to agricultural crops, in collaboration with agrochemical company Monsanto." [11].

Capital is a resource necessary to begin and operate a productive organization. Start-up capital is required for establishing a new organization and hiring initial staff, developing and designing the product/service, funding production capability and early production inventory, funding initial sales efforts and early operations.

As part of a capital structure, venture funds play an important role in starting new production $Y_{S}$ in an economy, as shown in Figure 12.

We see that investments by venture capital funds in new business start-ups did increase Production in the nation. Venture capital funds operated capital in an economy both ideally and realistically.

\section{U.S. Conglomerates}

Now we turn to the case of the United States form of the holding company in the second half of the twentieth century, as corporate conglomerates. U.S. corporate conglomeration began for several reasons:

1) Growth by Innovation: Launching new product lines and new businesses, financed by cash flows from existing businesses; 


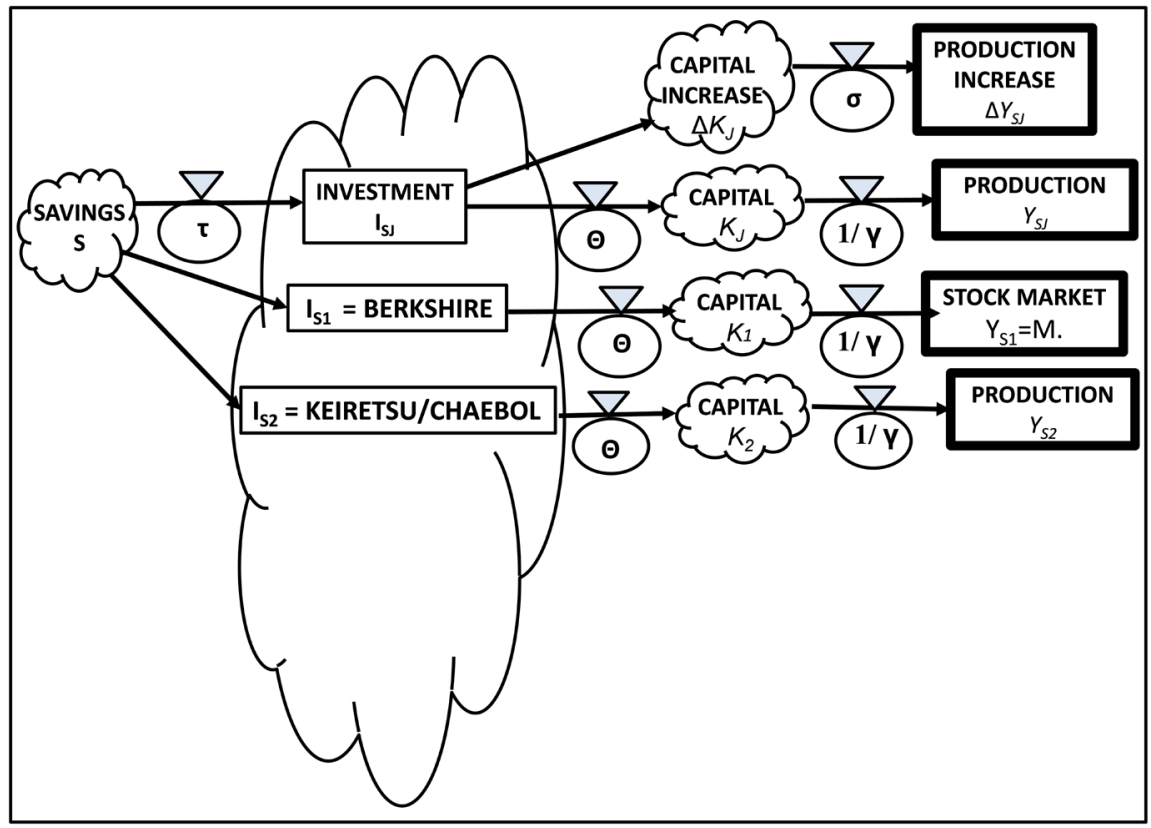

Figure 11. Zaibatsu/Keiretsu or chaebol investment $\mathrm{IS}_{2}$ in national production, zaibat$\mathrm{su} /$ keiretsu or chaebol investments in economic growth.

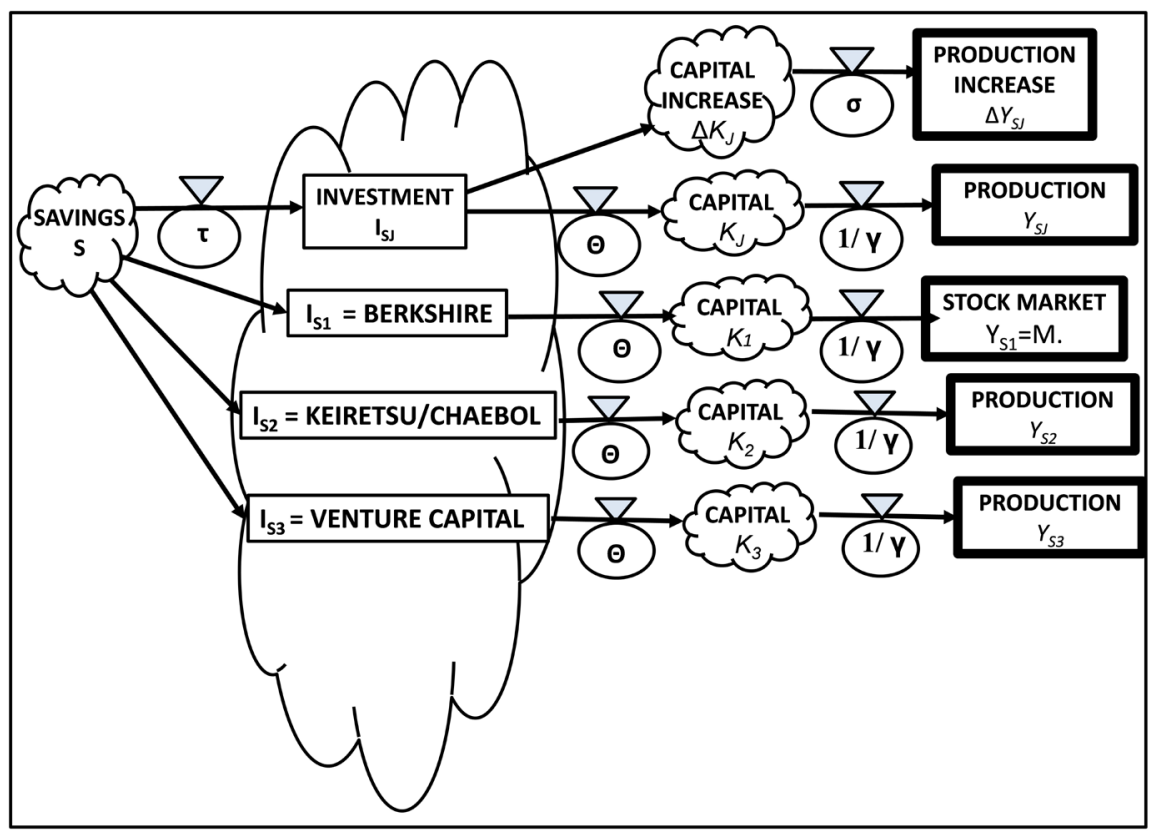

Figure 12. U.S. venture capital funds investment $\mathrm{I}_{\mathrm{S} 3}$, U.S. venture capital funds.

2) Growth by Acquisitions: Buying businesses with lower P/E ratios, as encouraged high valuation by financial markets of growing firms,

3) Surviving Economic Cycles: Balancing companies in different sectors impacted differently by economic recessions;

4) Improving Coverage of Market: Extending coverage of niches in a market to increase overall market share,

5) Manipulating Corporate Debt. Loading an acquired company with the debt 
of its purchase.

For example, one of the first U.S. conglomerates, Textron, was created by Royal Little. Earlier in 1923, Little had founded a company called Special Yarns Corp. in Boston, Massachusetts. The 1930s depression was hard, and the company struggled to stay alive. After the war, the textile business turned out to be highly cyclic, with a low return on capital. One of the reasons for this was that the industry expanded production capacity by reinvesting profits, reluctant to pay out high dividends or taxes. On June 30, 1952, Roy Little held a special stockholders' meeting to change the articles of association to buy businesses outside of textiles. His first acquisition was the Burkart Manufacturing Co. (which had begun by making horse blankets in St. Louis and then turned to making auto seat stuffing). Little then bought two more companies in 1954, Dalmo Victor and MB Manufacturing. In 1955, Little bought Homelite Corp. Textron then became one of the first conglomerates in the U.S.

The 1950s began two decades of widespread corporate conglomeration in the U.S. Growth companies, having high price/earnings ratio (P/E) valuations in the stock market, enabled them to buy no-growth companies (having lower $\mathrm{P} / \mathrm{E}$ stock valuations). But over the long term, corporate conglomeration in the U.S. had not provided a robust strategy. After companies were assembled, they often later were taken apart, when their stock price lagged behind the market. U.S. corporate conglomeration has been subject to the moods of the U.S. stock market-having periods of conglomeration when the market is rising and de-conglomeration when the market is falling. (As we noted, Berkshire Hathaway was the exception to the failure of long-term conglomeration in the U.S., due to its insurance businesses (insurance) at its core portfolio.) Figure 13 shows that capital funds for conglomerate mergers did not increase Production but decreased Production $\left(-\Delta Y_{S 4}\right)$, because the capital increase was as non-productive debt.

The decrease in Production often occurred because mergers often resulted in a decrease in employment, to justify "synergy" in the mergers. U.S. corporate conglomeration benefited executive management, but not necessarily shareholders or employees-not ideal for an economy but realistic.

\section{Wall Street Junk Bonds}

Finally, we turn to a case of corporate conglomeration, not for mergers, but to buy companies by manipulating their debt: junk-bond-funding of leveraged-buy-outs. Beginning in the United States in the 1980s, leveraged buy-outs began changing the ownership and direction of corporate strategy. This was because, in the United States, corporate law made it easy to change control of a business, by loading debt onto a purchased corporation. A raider would issue bonds without a present collateral value and use these to buy a corporation, for a future collateral value. Once the business was purchased, the income from the acquired business would be used to pay off junk bond. In this way, a financier (corporate raider or hedge fund) getting an investment bank to sell their junk bonds, could buy U.S. companies-nearly for free. 


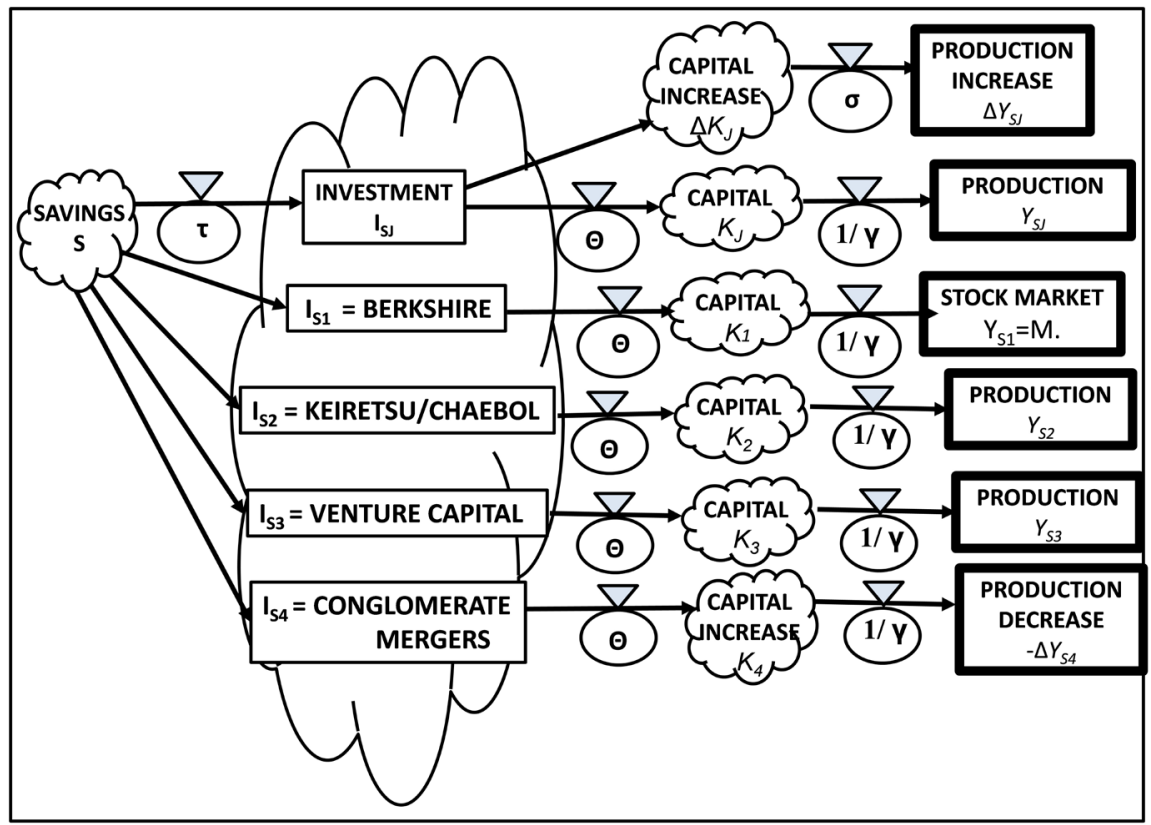

Figure13. Conglomerate mergers decreasing production, conglomerate mergers.

Sine the junk bonds were issued without present collateral, the junk bonds were highly risky. If the bond issuer failed; there was no underlying asset to seize. Why were they issued and sold? The issuer could use money the bonds raised to buy companies which did have assets; and these purchases were called "leveraged buy-outs". The junk bond innovation of Wall Street financed the leveraged buy-outs of ongoing businesses-but loaded the businesses with debt, reducing the productivity and competitiveness of a "captive" business-and thereby the competitiveness of the U.S. economy.

Suzanne Mcgee wrote about the "junk bond" financial innovation: "At a lavish dinner celebrating the fortieth anniversary of Institutional Investor magazine in 2007, Henry Kravis, a cofounder of the giant buyout firm KKR, was one of the evening's honorees-the forty 'Legends of Wall Street.' (That group also included John Gutfreund of Salomon Brothers.) In his speech, Kravis chose to laud Michael Milken, the investment banker who had popularized the 'junk bond' during the 1980s. Without Milken, Kravis told the audience, KKR couldn't have done the gargantuan deals that made it famous, and the entire buyout business (which had generated $\$ 357$ billion in deals in the United States alone the previous year, each of which produced massive fees for Wall Street investment banks) would have been stillborn." [12].

In 1970, Drexel Firestone was an investment bank focused upon selling bonds and providing stock trading services. Michael Milken began working as a bond salesperson. In 1973, I. W. Burnham purchased the firm and changed its name to Drexel Burnham Lambert. Burnham gave Milken $\$ 2$ million to trade in bonds and Milken doubled it in one year. Burnham increased the capital available to Milken to trade and gave him a 35 percent commission on trading profits. Connie Bruck wrote: "The world that Milken created for his faithful... would trans- 
form the face of corporate America. It would introduce terror and mayhem into countless corporate boardrooms. It would cause frightened managements to focus on short-term gains and elaborate takeover defenses... It would cause the loss of jobs, as companies were taken over and broken up... In doing all these things, the good and the bad, Milken's machine would stir hatreds and prejudices... Experts would debate whether the value that Milken's onslaught had added to American business outweighed the damage..." [13].

Milken focused on selling and trading bonds without underlying assets, "junk bonds". Junk bonds had existed for a long time, as bonds without adequate evidence that the corporation which issued the bond could fulfill its financial contract. What Milken did was to create a new market for a new kind of junk bond-a bond without past-value but perhaps future-value. The junk bonds were issued to buy-out existing companies. And for this junk bond market there were new sellers (buy-out artists and hedge-funds) and new buyers (savings \& loan banks, insurance companies, and pension funds). This scheme is modeled in Figure 14, for a financial market trading "junk bonds".

In this model of Drexel's junk bond market, the investment bank of Drexel Burnham formulated junk bond offerings for corporate raiders. The Savings \& Loan Bank industry (then recently deregulated) eagerly bought the junk bonds because of their high interest rates. Other financial institutions, such as insurance companies, also bought the junk bonds. A corporate raider used the proceeds from the junk-bond offering to buy out a publicly-listed company. Then the raider transferred the junk-bond debt onto the books of the bought company, for the company to pay off over time. When the US junk bond market collapsed in the 1980s, many of the S\&L banks went bankrupt, as their holding of junk bonds became worthless.

Milken at Drexel stimulated the 1980s junk bond market, with more and more "corporate raiders" going to Drexel for a bond offering. They then bought control of a company by buying the corporation's stock, using the junk bond financing. With this "junk bond" funding in the early 1980s, over a quarter of American corporations were so "traded"-taken over. Connie Bruck has listed some of the well-known corporate raiders in the 1980s, who included: Carl Icahn, Victor Posner, Nelson Peltz, Robert M. Bass, T. Boone Pickens, Harold Clark Simmons, Kirk Kerkorian, Sir James Goldsmith, Saul Steinberg and Asher Edelman. Connie Bruck wrote that: "Michael Milken raised pools of capital for the raiders through Drexel's junk bond offerings. For example, in 1984, Milken sold a $\$ 750$ million blind pool of junk to enable Ronald Perelman to take over Revlon, a leading cosmetics maker. Perelman sold off four of Revlon's divisions to reduce debt and later in 1966, Perelman sold his stock in Revlon through a public offering which made Revlon again a public company.” [13]. A captured corporation (such as Revlon), between being "private" and then flipped again as "public", had been greatly burdened to handle the enormous junk debt.

The profitability derived from transferring the debt liability from the "trader" 


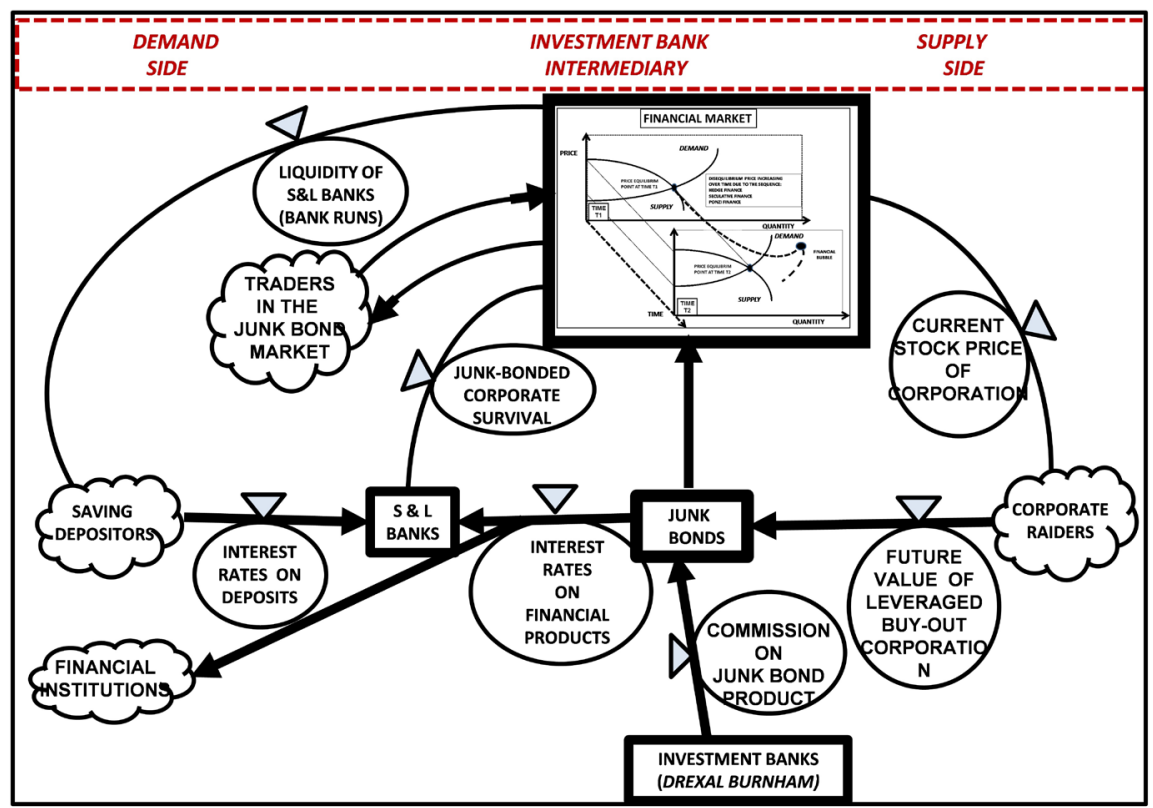

Figure 14. Financial Market of Junk Bonds to Fund Corporate Leveraged-Buy-Outs, financial market of junk bonds to fund corporate leveraged-buy-outs.

to the "traded corporation". The "take-over raider" which issued "junk bonds" as the raider's liability; but the liability was next transferred by the raider onto the captive corporation. The raider could do this by taking the company private in the "buy-out". Then as a private company, the raider could transfer his bond-liability onto the company books, since the company was the raider's private property. In this way, a "taken-over" captive company' was loaded with the additional debt to pay for its own "take-over". This was a private good for the take-over artist but not necessarily a private good for the corporation. The corporate raider "investor" then had no further liability for the junk bonds previously issued-a nice financial trick.

Kohlberg Kravis, Roberts \& Co (KKR) was a private equity company which pioneered the trading of American corporations through "leveraged buy-out" financing. It was founded in 1976 by Jerome Kohlberg, Henry Kravis and George Roberts. They had worked together at Bear Sterns, where they started some leveraged buy-outs. Then they left to form their own firm; and proceeded to buy out over 160 companies worth $\$ 400$ billion in private equity transactions.

An example of the heavy burden of debt KKK could put upon a company was its "captured" First Data Corp. Henny Sender wrote: "Sometime soon (in 2014), KKR hopes to mark its investment in First Data back to 100 cents on the dollar, allowing the private equity group to start preparing a heavily indebted company it took private at the peak of the 2007 buyout boom for an initial public offering ... It has been a long way back for a $\$ 30$ bn deal that was one of the largest buyouts ever. At the depths, KKR held the payments processor and information company on its books at 60 - 70 cents." [14].

As a private company owned by KKK, First Data had been loaded with the 
junk debt (which KKK transferred from it to First Data). Then First Data was no longer "profitable", as its revenues after 2007 went only to pay expenses to service interest on junk debt. Thus the value of First Data had declined to $60 \%$ $70 \%$ of it "buy-out" price; and in 2014, KKK needed to invest some of its own capital into First Data to make it a competitive company-and to make it show profits, so that KKK could "flip it" by taking it again public. In 2014, Greg Roumeliotis wrote: "First Data is one of many corporate cleanups quietly underway in the world of private equity, as the industry deals with a debt binge in the years before the 2008 financial crisis." [15].

The captured corporation had to pay off the junk debt used to capture the corporation; and often could make no investments for the future (such as R \& D and new products). Later (and hopefully) after the captured corporation paid off some of the debt and achieved profits again, the corporation could be taken public again, reaping enormous profits on the investment by the raiders-providing an infinite rate of profit to the raider-trader because they borrowed the money and never held liability for the debt. Some of the stock sales proceeds might be used to pay down some of the debt; but proceeds first went to enrich the corporate raider. Wall Street investment banking went from helping corporations to begin and grow to "flipping" corporations-a private good with a questionable public good.

But junk bonds had also an impact upon buyers and the economy-creating "bank runs" on the U.S. Savings \& Loan banks (S \& L) in the late 1980s. From 1986 to 1995 , one third of the S \& L banks went bankrupt. S\&L banks were chartered to fund home mortgages in the United States, restricted to mortgages with homes as collateral. In 1980 and 1982, the U.S. Congress deregulated the S\&L industry, allowing these banks to invest in anything and many invested in Milken's junk bonds. When Milken went to jail and the junk bond imploded then, the S \& Ls holding junk bonds went insolvent. The U.S. regulatory agencies then closed 1043 out of 3234 S \& Ls. Later the junk bond market revived; and hedge funds purchasing corporations with bank lending continued. Figure 15 depicts the Hedge Funds contribution to the US capital structure, with the J-th index of $J=5$.

We see that the increase of capital $\mathrm{K}_{5}$ contributed by a Hedge Fund junk-bond loan did not increase Production in the U.S. economy but decreased Production $\left(-\Delta Y_{S 5}\right)$ because of the enormous non-productive debt put upon a captured corporation (requiring it to cut costs and not invest in improving productivity) in order to bay off the burden of the debt. Hedge Fund capital investment was not ideal economically but only realistic_creating private good with little public good.

\section{Discussion: Impact of Capital Structures on Global Competition}

Why is it important to understand capital structures and their investments in an economy? It is important because all large global companies are now organized 


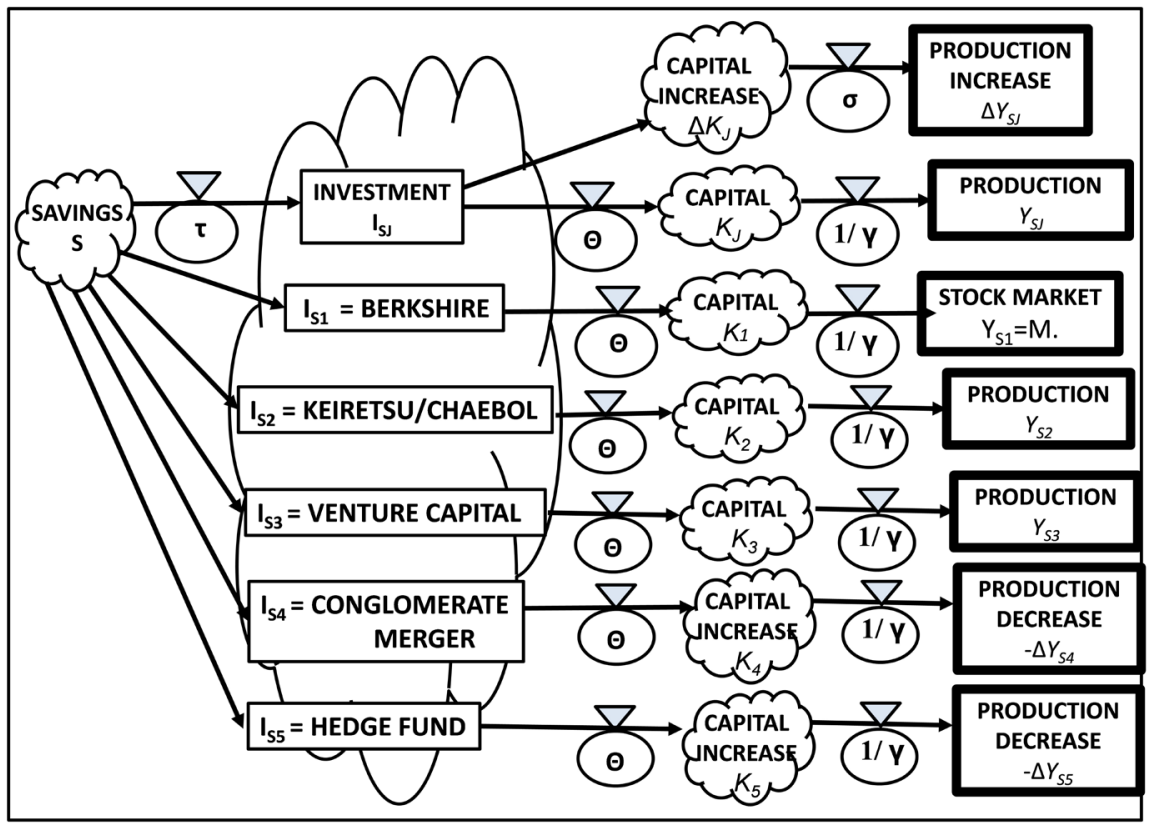

Figure 15. Hedge Funds Capital Structure Contribution with Leveraged-Buy-Outs, hedge funds leveraged buy-outs.

in holding-company form; and this form has influenced the capital structures of national economies and their competitiveness. An illustrative example of how the capital structures enabled international competition occurred in the memory chip industry. In 1970, Americans invented the memory chip, but in 1981 they lost the global market to Japanese firms (in their keiretsu capital structure). Later in 2000, the Korean holding-company Samsung (in its chaebol capital structure) seized the global memory chip market.

In 1972, Intel innovated the DRAM IC memory chip and dominated production of it, until 1981 when Japanese competitors introduced a next-generation 64 K DRAM chip 8 months before Intel introduced this into the market. With that 8 months lead, Japanese competitors seized the global memory chip market; and American companies, including Intel, withdrew from the market-stopped producing memory chips. Even the strong firm Intel was forced from the memory chip market-in that first creative-destruction in the global memory chip industry.

The competitive challenge was the cost of a new chip factory to produce the next-generation memory chip after the $64 \mathrm{~K}$ chip. The cost required bank loans to build new chip factories, and at the time, commercial loan rates in the U.S. were twice the rates in Japan. In the U.S. capital structure, interest rates on commercial loans ranged from $6 \%$ to $9 \%$. This compared to $3 \%$ interest which the people of Japan were receiving from savings accounts in the Japanese Postal Office, and these savings were available to the keiretsu as a source of capital. This meant that capital costs for the Japanese chip industry were one-half to one-third less than capital costs for the U.S. chip industry-putting the U.S. firms at a serious disadvantage in a manufacturing investment to stay in the 
memory chip industry. Japan's ability to continue funding the chip industry was facilitated by the keiretsu, which succeeded the zaibatsu, continuing as a group of interlocking companies controlled by a core bank.

By 1981, Japanese electronic firms were producing not only chips but also consumer electronic products, generating revenue from both components and consumer products. Also we recall that earlier in 1971, they had been assisted by the Japanese governmental agency MITI to acquire the semiconductor technology of Large Scale Integration, producing $16 \mathrm{~K}$ memory chips by 1976 . These electronic firms were each a part of a keiretsu and financed by their keiretsu bank to build $16 \mathrm{~K}$ chip production capacity in 1976 and then, significantly, $64 \mathrm{~K}$ chip production in 1981.

In contrast, the U.S. semiconducting chip firms had been small single business firms, and did not produce electronic consumer goods nor had a cash flow from any product other than their semiconductor IC chips. They belonged to no corporate group, with a bank at the center, such as a keiretsu. Consequently, when keiretsu-financed Japanese electronic firms grabbed the $64 \mathrm{~K}$ DRAM market first, U.S. firms had no cash flow to continue nor to invest for the next generation of chips. All U.S. firms singly devoted to memory chips went bankrupt.

Only U.S. semiconducting IC firms to survive were those which also were producing logic chips (e.g. Intel, Motorola, Texas Instruments). The Schumpeterian creative destruction of the U.S. national memory chip business was due to capital structure and corporate organization in the U.S.- which together had not facilitated investments in next-generation chip product.

Later in 2000, a second Schumpeterian creative destructions hit the Japanese chip firms when the Korean chaebol Samsung introduced the $1 \mathrm{M}$ bit memory chip a year ahead of Japanese chip manufacturers. Respective capital structures between Japan and Korea played an important role in both technology discontinuities. Chaebol companies owned stock in each other and were able to finance each other's operations, because all ultimately were under control of a holding company (chaebol) of the founding family.

In South Korea, Park Chung He had encouraged chaebols to industrialize South Korea for exports. The government encouraged the acquisition of new technologies and built the universities to educate the engineers to design new technologies. The government actively selected some chaebols to undertake major technology acquisition and development projects and guaranteed their foreign loans.

In the Samsung chaebol, cash flow from other Samsung companies (along with foreign loans guaranteed by the government) provided the capital for Samsung Electronics to succeed in the development and production of the series of technology discontinuities from the $64 \mathrm{~K}$ DRAM chip to the 4 G DRAM chip. In 1996-97 during the Asian financial crisis, South Korean was hard hit in this crisis. The Samsung group had large foreign debts, but it used the crisis to restructure the group onto a sound financial basis. Afterwards, with large revenues 
from the $4 \mathrm{G}$ and $8 \mathrm{G}$ DRAM and NAND flash-drive memory discontinuities, Samsung dominated memory chip production. The Korean Schumpeterian creative-destruction drove first the Japanese competitors out of the memory chip business.

The two creative-destructions in the global memory chip industries in the late twentieth century illustrate the importance of capital structures in a nation to finance economic competition. The form of the holding companies, keiretsu and chaebols, financed successful industrial competition in memory chips; while, in the same time period, the holding companies of U.S. hedge funds financed the "flipping" of U.S. companies.

\section{Summary}

The assumption in macro-economics that all savings-investments go to production or to increasing production is idealistic but not always empirically accurate. A vectorized Harrod-Domar macro-economic model enables the empirical description of how the form of a holding company directs investments in an economy. It can include the concept of a "capital structure" in explaining the flow of capital in a national economy. Capital investments can also go into only increasing wealth and, in the process, decreasing production. Adding the concept of a "capital structure" into a macro-economic model can improve the accuracy of the model by enabling empirical verification of capital flows. Different kinds of holding companies direct the flow of investment capital into different uses. Vectorized macro-economic models can trace where investment in an economy actually goes, thereby improving the realism of the model.

Sometimes, holding companies have strategically benefited shareholders or sometimes benefited a founding family or sometimes benefited corporate executives or sometimes benefited corporate raiders and hedge funds. The capital structure of some holding companies has contributed to growth in national employment and some only to wealth and some even to decreasing production. How the strategic control of capital has been exercised in a holding-company form has made major differences in economic history.

Footnote: The later Solow model of economic growth was not used in this analysis because it does not directly depict the relation of capital $\mathrm{K}$ to production Y, as did the earlier Harrod-Domar model. Solow wrote: "Output is produced with the help of two factors of production, capital and labor, whose rate of input is $\mathrm{L}(\mathrm{t})$. Technological possibilities are represented by a production function: $\mathrm{Y}=$ F (K, L).” [16]. Solow then substituted a ratio $\mathrm{r}$ of capital $\mathrm{K}$ to labor $\mathrm{L}$, resulting in a model dependent on the variable of labor $\mathrm{L}$. This resulted in a model where capital K was still implicitly linearly proportional to production $\mathrm{Y}$ (as in the earlier Harrod-Domar model). Thus in terms of translating to a graphic system model, the Harrod-Domar model is more direct in expression than the later Solow model, and the dependence of capital $\mathrm{K}$ to production $\mathrm{Y}$ is the same in both models. 


\section{Conflicts of Interest}

The author declares no conflicts of interest regarding the publication of this paper.

\section{References}

[1] Van den Berg, H. (2013) Growth Theory after Keynes, Part I: The Unfortunate Suppression of the Harrod-Domar Model. The Journal of Philosophical Economics, 7, 2-28.

[2] Betz, F. (2015) Disequilibrium Systems Representation of Growth Models-HarrodDomar, Solow, Leontief, Minsky, and Why the U.S. Fed Opened the Discount Window to Money-Market Funds. Modern Economy, 6, 1189-1208. https://doi.org/10.4236/me.2015.612113

[3] Berle, A.A. and Means, G.C. (1967) The Modern Corporation and Private Property. 2nd Edition, Harcourt, Brace and World, New York.

[4] Porter, M. (1985) Competitive Strategy. The Free Press, New York.

[5] Betz, F. (2002) Strategic Business Models. Engineering Management Journal, 14, 3-9. https://doi.org/10.1080/10429247.2002.11415145

[6] Berkshire Hathaway Inc. (2016) 2015 Annual Report Form (10-K) (XBRL). United States Securities and Exchange Commission. https://www.nytimes.com/2018/02/24/business/dealbook/buffetts-annual-letter-ber kshire.html?rref\%20=\%20collection\%2Ftimestopic\%2FBuffett\%2C\%20Warren\%20 E

[7] Eavis, P. and Grocer, S. (2018) Buffett's Annual Letter: Berkshire Records \$29 Billion Gain from Tax Law. The New York Times, New York.

[8] Morikawa, H. (1992) Zaibatsu: The Rise and Fall of Family Enterprise Groups in Japan. University of Tokyo Press, Tokyo.

[9] Alletzhauser, A.J. (1990) The House of Nomura. Arcade Publishing, New York.

[10] Kang, M.H. (1996) The Korean Business Conglomerate: Chaebol Then and Now. Center for Korean Studies, University of California, Berkeley.

[11] Cookson, C. (2018) Gene Editing Pioneers Launch US Start-Up to Tackle Disease. Financial Times, London.

[12] Mcgee, S. (2010) Chasing Goldman Sachs: How the Masters of the Universe Melted Wall Street Down... And Why They'll Take Us to the Brink again. Crown Publishing Group, New York.

[13] Bruck, C. (1988) The Predators' Ball. Simon and Schuster, New York.

[14] Sender, H. (2014) KKR Seeks to Make the Numbers Work at First Data. Financial Times. https://www.ft.com/content/75ba0e9e-f42f-11e4-bd16-00144feab7de

[15] Roumeliotis, G. (2014) KKR Doubles Down on First Data, Leading \$3.5 Billion Investment. Reuters.

http://www.reuters.com/article/2014/06/19/firstdata-kkr-idUSL6N0P03AL20140619

[16] Solow, R.M. (1956) A Contribution to the Theory of Economic Growth. The Quarterly Journal of Economics, 70, 65-94.

https://www.jstor.org/stable/1884513?seq=1\#page_scan_tab_contents https://doi.org/10.2307/1884513 